\title{
Challenges and Tools for In Vitro Leishmania Exploratory Screening in the Drug Development Process: An Updated Review
}

\author{
Anita Cohen * and Nadine Azas
}

Citation: Cohen, A.; Azas, N. Challenges and Tools for In Vitro Leishmania Exploratory Screening in the Drug Development Process: An Updated Review. Pathogens 2021, 10, 1608. https://doi.org/10.3390/ pathogens 10121608

Academic Editors: Coralie L'Ollivier and Aurélien Dumetre

Received: 4 November 2021

Accepted: 7 December 2021

Published: 10 December 2021

Publisher's Note: MDPI stays neutral with regard to jurisdictional claims in published maps and institutional affiliations.

Copyright: (c) 2021 by the authors. Licensee MDPI, Basel, Switzerland. This article is an open access article distributed under the terms and conditions of the Creative Commons Attribution (CC BY) license (https:// creativecommons.org/licenses/by/ $4.0 /)$.
IHU Méditerranée Infection, Aix Marseille University, IRD (Institut de Recherche pour le Développement), AP-HM (Assistance Publique-Hôpitaux de Marseille), SSA (Service de Santé des Armées), VITROME (Vecteurs-Infections Tropicales et Méditerranéennes), 13005 Marseille, France; nadine.azas@univ-amu.fr

* Correspondence: anita.cohen@univ-amu.fr

\begin{abstract}
Leishmaniases are a group of vector-borne diseases caused by infection with the protozoan parasites Leishmania spp. Some of them, such as Mediterranean visceral leishmaniasis, are zoonotic diseases transmitted from vertebrate to vertebrate by a hematophagous insect, the sand fly. As there is an endemic in more than 90 countries worldwide, this complex and major health problem has different clinical forms depending on the parasite species involved, with the visceral form being the most worrying since it is fatal when left untreated. Nevertheless, currently available antileishmanial therapies are significantly limited (low efficacy, toxicity, adverse side effects, drugresistance, length of treatment, and cost), so there is an urgent need to discover new compounds with antileishmanial activity, which are ideally inexpensive and orally administrable with few side effects and a novel mechanism of action. Therefore, various powerful approaches were recently applied in many interesting antileishmanial drug development programs. The objective of this review is to focus on the very first step in developing a potential drug and to identify the exploratory methods currently used to screen in vitro hit compounds and the challenges involved, particularly in terms of harmonizing the results of work carried out by different research teams. This review also aims to identify innovative screening tools and methods for more extensive use in the drug development process.
\end{abstract}

Keywords: zoonotic visceral leishmaniasis; in vitro exploratory antileishmanial screening; cell viability; fluorescence; bioluminescence; RNA interference; CRISPR-Cas9; omics-based methods; bioand cheminformatics

\section{Introduction}

The leishmaniases are a group of vector-borne diseases common to humans and certain mammals, mainly the dog, for zoonotic visceral forms. They are caused by flagellated protozoan parasites belonging to the Leishmania genus. At least 20 species are encountered in human pathology [1]. These parasites are transmitted through the bite of an infected hematophagous female phlebotomine sand fly.

There was an endemic in 98 countries and territories in 2020 [1], and the geographic distribution of these diseases evolved according to the movements of the insect vector driven by climatic and environmental changes (such as deforestation and urbanization) [2]. These diseases mainly affect poor people in Africa, Asia, and South America and are associated with malnutrition, population displacement, poor housing, weak immune system, and a lack of resources [1,2]. Clinically, there are three main forms of leishmaniasis [1]: (i) Cutaneous leishmaniasis, which represents the most common form; (ii) Mucocutaneous leishmaniasis; and (iii) Visceral leishmaniasis, which is potentially fatal if left untreated. Two epidemiological types of visceral leishmaniasis coexist worldwide. Firstly, the main 
epidemiological type around the Mediterranean basin involves L. infantum and is represented by zoonotic visceral leishmaniasis. This type is clinically characterized by the triad of mad fever, anemia, and splenomegaly and is transmitted from dogs to humans. Secondly, anthroponotic visceral leishmaniasis is more commonly found in India. It is characterized by additional adenopathy and cutaneous signs and is transmitted from human to human. Today, more than 1 billion people live in areas endemic for leishmaniasis and are at risk of infection. An estimated 30,000 new cases of visceral leishmaniasis occur annually, according to the WHO [3]. In recent years, a downward trend has been observed in the number of reported visceral leishmaniasis cases, notably due to the effect of the WHO's visceral leishmaniasis elimination program [4]. In 2020, about $87 \%$ of global visceral leishmaniasis cases were reported from eight countries (Brazil, Eritrea, Ethiopia, India, Kenya, Somalia, South Sudan, and Sudan) [1].

In this context, zoonotic visceral leishmaniasis is managed by preventing and eliminating infections in dogs, the main parasite reservoir host, but the complexity of its transmission cycle involving humans, domestic animals, wildlife, and sand fly vectors must be considered. The treatment of human cases is therefore of particular interest. The currently available antileishmanial medicines [5] are mainly represented by amphotericin B (injectable and liposomal formulations), pentamidine, and pentavalent antimonials [6]. Miltefosine is the first and only oral drug approved for leishmaniasis [7]. Paromomycin, usually administered intramuscularly, was shown to be effective in Indian visceral leishmaniasis [5]. A topical formulation is also available for cutaneous leishmaniasis [5]. Azole medicines were also reported as having variable efficacy [5]. The treatment regimen should follow national and regional guidelines, if applicable [4,8]. Nevertheless, all these medicines present several limitations. First, they are often long-term treatments. Furthermore, most of these treatments require parenteral administration. Secondly, many severe adverse side effects have long been identified for these products [7,9] and, with the liposomal formulation that reduces the nephrotoxic side effects of amphotericin $B$, that galenic solution carries a non-negligible cost and the requirement of cold chain maintenance [7]. Thirdly, the parasite's development of increasing resistance [7-10] contributes to the low effectiveness of these treatments. Moreover, Leishmania species-dependent variations were demonstrated in drug-susceptibility [11].

Therefore, several strategies to overcome antileishmanial drugs unresponsiveness should be considered [12], as well as the promotion of research programs, notably for the screening of new antileishmanial compounds. Therefore, in this paper, we focus on the very first step of the development process of a potential drug and will review existing exploratory screening methods to identify in vitro hit compounds against Leishmania. First, we discuss the challenges involved in implementing exploratory in vitro screening against Leishmania. Then we present recent technological advances enabling the development of new research tools in the drug development process.

\section{Challenges Involved in Implementing Exploratory Screening to Identify In Vitro Hit Compounds against Leishmania}

Exploratory pharmacological in vitro screening is a method of scientific experimentation requiring the use of technical and technological resources to study and select, in a chemical library, the active hit compounds on a biological target. The identified hit compounds are starting points for pharmacomodulation studies to design and develop potential drugs. Therefore, exploratory in vitro screening is the very first key step in the drug development process. Given this, the instrumentation used to perform such screening is crucial. Indeed, the choice of equipment can result in significant differences in costs, required handling time, and quality of data (reproducibility and repeatability). From manual testing to semi-automated or even fully automated testing, these criteria could vary widely and represent a challenge for harmonizing results obtained by different research teams. Nevertheless, more and more examples of efficient high throughput screening against Leishmania are described in the literature [13-18]. 
Another challenge posed by these exploratory in vitro screening tests is the biological target itself: the Leishmania parasite. Indeed, the exploratory screening for Leishmania involves in vitro exploratory screening on a whole protozoan parasite that exists in two morphological forms (promastigote and amastigote), which means there is a multitude of potential molecular targets. The Leishmania's lifecycle requires the presence of two entities: the sand fly vector and a mammalian host. Various developmental stages throughout this lifecycle are required, but these different stages (promastigote and amastigote forms) involve many variations in diverse metabolic, biochemical, and biological pathways, which were progressively detailed in the literature [19-24]. Various Leishmania forms are used experimentally in vitro to develop exploratory screening tests, which are promastigotes, intracellular amastigotes, and axenic amastigotes. These latter forms represent amastigotes that were adapted to grow and develop outside their host cells in a growth medium that mimics the intracellular conditions [25-27]. Therefore, it appears complicated to consider only one parasite form in the framework of an exploratory in vitro screening. If rapid primary screening can be performed on extracellular promastigotes and axenic amastigotes, it would be essential to confirm and identify false positives during a secondary screening of identified hit compounds on clinically relevant intramacrophagic amastigote forms [14]. Nevertheless, this strategy does not prevent false negatives represented by hit compounds specific to intracellular amastigotes without highlighted activity on extracellular forms [28]. Thus, exploratory screening tests designed to facilitate the rapid testing of a large number of compounds are usually performed on the extracellular promastigotes or axenic amastigotes, which both enable the performance of high throughput screenings with high reproducibility [29]. Although some consider that promastigotes may not be as relevant as axenic amastigotes for screening purposes [30], there is still a lack of correlation between axenic artificial forms and intracellular amastigotes [14]. As such, models using host cells currently remain the gold standard in determining compound sensitivity [31] since they provide essential information about the tested compound's activity in the parasite's natural environment. Nevertheless, these models also reveal variation factors and potential biases, such as a low replication rate of amastigotes compared to promastigotes [32,33], the influence of the macrophage infection rate [34], and the variety of host cells used (primary cells or cell lines) [35]. Thus, although many studies show a correlation between the results obtained on in vitro promastigotes and (axenic) amastigotes [36-41], it seems important to take all these various factors and potential biases into account before implementing secondary screenings and interpreting them.

Another challenge in terms of harmonizing work carried out by different research teams is the wide variety of existing options for detection, acquisition, and data processing systems [42]. Thus, cell viability detection was extensively used in the exploratory screening of antileishmanial compounds, especially for primary screenings on extracellular forms [27,36-70]. Indeed, there are many colorimetric assays that are usable, simple, inexpensive, and suitable for large-scale screening $[43,44]$. Some of those are poorly illustrated in the existing literature, such as the trypanothione reductase assay [45] or acid phosphatase assay [46-49], while others are widely proven, notably, those related to intracellular metabolizing salts such as the most famous MTT assay (3-(4,5-dimethylthiazol-2-yl-2,5-diphenyl tetrazolium bromide) [38,50-59]. This yellow salt is reduced to purple formazan crystals in living cells, allowing for easy determination of parasite viability. Other analogous tests are also described, such as the one using Alamar blue (resazurin) [27,60-67], an oxidationreduction indicator that changes its color from blue to red in living cells. The use of an analog of MTT, the MTS (3-(4,5-dimethylthiazol-2-yl-5(3-carboxymethylphenyl)-2-(4sulfophenyl)-2H-tetrazolium) [68-70], is also described. However, these tests are not very sensitive and are mainly used for low throughput screenings. Furthermore, direct counting could also be used to evaluate the leishmanicidal activity of tested compounds both in promastigote (motility of promastigotes and examination of non-viable parasites after staining) [71] and in amastigote (microscopic counting of infected macrophages and the number of parasites per macrophage after staining) assays [71]. This method has the advantage 
of not requiring expensive equipment, but it is time-consuming, laborious to perform, unsuitable for large-scale screening, and suffers from a lack of reproducibility. Moreover, the determination of inhibitory concentration $50 \%\left(\mathrm{IC}_{50}\right)$ may be inaccurate since the determination of parasite viability through a staining procedure is obviously difficult [25]. Different tools were developed to automate this tiresome microscopic counting [72,73]. As an example, can be cited an automated microscopic image analysis, which can be applied to the quantification of drug activity [74]. Of note is a methodology using a colorimetric $\beta$-lactamase assay described on intramacrophagic amastigotes of L donovani [16]. Nevertheless, in the field of cell viability analysis, flow cytometry constitutes an interesting alternative $[75,76]$, which is accurate and largely used to automate the reading of results. Another approach uses the detection and quantification of engineered cells expressing fluorescent gene reporters [77,78] such as green fluorescent protein (GFP) [32,79-81] and bioluminescent gene reporters such as luciferase [82-86], or a combination of both [87-90]. These methods are proven to be more sensitive and enable faster read-outs and higher throughput [91]. Moreover, reporter proteins bear or produce an easily detectable response that can be quantified even in intracellular conditions, leading to the development of many experimental models [92]. As an example, the use of a traceable bioluminescent marker, such as NanoLuc-PEST, that correlates specifically with parasite viability could provide a more relevant in vitro assay for use in both axenic and intramacrophage amastigote models. This system was already described in L. mexicana [93] and could be adapted to other Leishmania species since the employed reporter protein expression vector (pSSU-int) was already successfully used in the main species involved in pathology $[29,94,95]$. Furthermore, a recent comparison of several bioluminescent reporters in a cutaneous leishmaniasis model indicated that NanoLuc-parasites, despite high bioluminescence intensity in vitro, were shown to be inadequate in discriminating between live and dead parasites in drug screening protocols. Bioluminescence detection from intracellular amastigotes expressing NanoLuc-PEST, red luciferase (RedLuc), or conventional luciferase (Luc2) proved more reliable than microscopy to determine parasite killing [96]. Nevertheless, this technology also presents several limitations, including a potential antibiotic cross-resistance conferred by induced antibiotic resistance allowing the selection of recombinant parasites and the difficulty of adapting it to Leishmania clinical isolates. Furthermore, these genotypic modifications of parasites could result in phenotypic consequences, such as biological transformations.

\section{Recent Technological Advances Enabling the Development of New Research Tools in the Drug Development Process}

A common drawback of all the already cited methodologies is that they represent only phenotypic screenings. The molecular target(s) of identified hit compounds remains to be determined by suitable mechanistic studies, which also represent a challenge in many cases. Indeed, it often seems complicated to identify the molecular target(s) of in vitro original hit compounds, which is likely to have an impact on the number of products in development progressing from the preclinical to the clinical stage. The main impact is the acute scarcity of new drug candidates reaching clinical trials: there are 170 registered clinical trials on leishmaniases on the ClinicalTrials.gov database, of which only 21 are ongoing. Of those, 13 are interventional drug trials involving a curative treatment, and four of which involve a product being developed alone or in combination with others [97]. This difficulty in accurately identifying the molecular target(s) of hit compounds is even more surprising as the Leishmania genome sequence information $[98,99]$ was described and made available, along with significant research into the parasites' biology $[100,101]$. However, classical genome manipulation methods encounter some limitations in Leishmania, including difficulties in achieving gene knockouts because of the parasites' high genomic plasticity [102]. Nevertheless, recent advances in various technological areas suggest new possibilities for target-based drug discovery methods [103-105]. Ideally, a druggable target would be critically essential to parasites' growth or survival (such that an incomplete knockdown would result in parasites' death), be selective, 
and have a catalytic site or pocket in its structure (to optimize interactions with a small molecular inhibitor) [106,107].

Therefore, RNA interference (RNAi), defined as the mechanism through which genespecific, double-stranded RNA (dsRNA) triggers the degradation of homologous transcripts, should be helpful [108], but this approach has proven ineffective in several Leishmania species [109,110] due to the absence of RNAi-related genes, such as Argonaute [111,112]. Consequently, there are only a few published applications of the RNAi approach, particularly those described in cutaneous leishmaniasis pathogens such as L. braziliensis [108,113] and L. mexicana $[114,115]$. In visceral leishmaniasis, this RNA interference strategy was mostly used to understand the mechanism of L. infantum infection better, whether it be the study of the functional role of the CC chemokine receptor 5 (CCR5) [116] or that of Wnt5a signaling [117].

However, the CRISPR-Cas system is a real step forward [118]. Initially identified as a prokaryotic defense mechanism against plasmids and virus invasions, this CRISPR-Cas9 (Clustered Regularly Interspaced Short Palindromic Repeats linked to the Cas9 endonuclease protein) system has been used for genome editing and various applications for a decade [119]. Target recognition strictly requires the presence of a short protospacer adjacent motif (PAM) flanking the target site, and the subsequent R-loop formation and strand scission are driven by complementary base pairing between the guide RNA and target DNA, Cas9-DNA interactions, and associated conformational changes [120]. With it being simple, inexpensive, and efficient, this system has found some specific applications on leishmaniases since proof-of-concept in 2015 when the first CRISPR-Cas9 mediated genome editing tools were developed and demonstrated as being effective against L. major [121] and L. donovani [122]. In Leishmania, CRISPR-Cas9 results in double-strand DNA breaks, which can be resolved by several mechanisms, such as homologous recombination or microhomology-mediated end joining [123] as non-homologous end joining is thought to be absent in this parasite [124]. The adaptation and optimization of this approach for Leishmania spp. led to genetic engineering, identification of essential genes, and characterization of potential drug targets $[125,126]$. In particular, the method was improved in a CRISPR-Cas9 toolkit for quick and precise gene modification by integration of donor DNA, using engineered cell lines and drug selection of mutants, which was developed in L. major, L. mexicana [127] and validated in L. donovani [128]. As an example, this CRISPR-Cas9 approach led to the discovery that the leishmanial eIF4E cap-binding protein (LeishIF4E-3) is essential for the completion of the parasite lifecycle since the deletion of a single allele by the CRISPR-Cas9 system alters the cell morphology and results in parasite infectivity [129]. Lately, this system was successfully used to create individual null mutants for L. mexicana eukaryotic protein kinases (ePK) and phosphatidylinositol 3' kinase-related kinases (PIKK). Then, the generation of the L. mexicana kinome gene and a further systematic functional analysis of kinases led to identifying several pathways notably regulation of the parasite's replication, differentiation, and responses to stress which are divergent to humans, and which potentially could be targeted in the drug development process [130].

Furthermore, advances in omics-based methods also led to the identification of parasitic targets, representing another important tool for drug discovery. These technologies are increasingly used for target discovery and validation for protozoan parasites, including Leishmania [131,132]. Thus, a method that has been used with great success to find new drug targets in malaria [133] is in vitro evolution and whole-genome analysis (IVIEWGA). In this case, this method is more complex because the Leishmania genome is larger and diploid, in contrast to that of Plasmodium. In this method, parasites are exposed to sublethal concentrations of hit compounds already identified in phenotypic screens. In order to identify the genetic basis of their resistance, the genomes of the resistant clones are analyzed using tiling microarrays or, more typically, using whole-genome sequencing and are compared to the sensitive parent clone. In many cases, newly emerged genomic lesions are found in genes that are predicted to encode the targets. IVIEWGA recently led to the identification of two new antileishmanial drug targets. The first is the $\beta 4$ subunit of the proteasome 
that catalyzes protein degradation through the ubiquitin-proteasome pathway [134]. This target was identified by analyzing GNF3943; the lead compound was identified using a phenotypic screen for compounds that are broadly active against L. donovani, Trypanosoma cruzi, and Trypanosoma brucei. Next, 3000 compounds were synthesized, from which two were used for IVIEWGA experiments that resulted in two independent mutations in the proteasome $\beta 4$ subunit. These results suggested that the proteasome, which is essential in eukaryotic cells, was the target. The second is the cyclin-dependent kinase 12 (CDK12), which is involved in the control of transcription and cell division [135]. In this work, a hit compound (DDD853651/GSK3186899) from a phenotypic screen was used for a combination of chemical proteomics and IVIEWGA experiments leading to the identification of CDK12 as a parasite target. The advantage of targets discovered through this IVIEWGA method is that they are, by default, chemically validated and druggable, though complementary studies may be needed to validate the targets and their clinical relevance further. Metabolomics can also be applied to investigate metabolic pathways and potential mechanisms of action or resistance of selected hits or drugs [136]. Thus, in the context of zoonotic visceral leishmaniasis, a multiplatform metabolomic approach was developed and described [137] to elucidate the basis of the mechanisms of action and resistance of L. infantum to antimonial derivatives. This work was performed through an untargeted analysis of metabolic snapshots of several parasites' populations (treated/untreated and resistant/responders) using a multiplatform approach to determine the widest possible coverage of $L$. infantum metabolome and through a ${ }^{13} \mathrm{C}$ monitoring of the origin of the highlighted alterations.

Bioinformatics and cheminformatics are also powerful tools for screening and identifying drug targets in Leishmania, mainly based on their divergence from the host and the essential nature of their biological function. Indeed, computational approaches have gained prominence in the last two decades as reliable approaches in the prediction of druglike compounds with much ease [106]. This approach aims to identify structure-activity relationships (SARs) in order to design optimized compounds that could be screened in silico [138,139]. In this way, a growing body of work was published on structure-based computational approaches and pharmacophore-based virtual screenings, such as the in silico high throughput screening and the molecular docking published by Saki et al. in 2019 [140]: this work identified five potent antileishmanial ligands for lipophosphoglycan (LPS) receptor, and two for $\gamma$-glutamylcystein synthase $(\gamma$-GCS) receptor in L. infantum among 20,000 FDA approved drugs. In 2021, similar computational approaches notably led to identifying phytochemical inhibitors of squalene synthase [141] and selective inhibitors of dihydrofolate reductase [142] in L. donovani. Allosteric modulators of superoxide dismutase in L. chagasi were also identified [143]. However, virtual screening appears ever more efficient with the development of methodological tools [140,144], but several potential biases were reported [145]. For this reason, although this approach is very interesting, fast, and a cost-efficient alternative to high-throughput screening, the results should be tested and validated experimentally [146-148] afterward. Among the most recently published works are those of Khatoon et al. [148], which identified original coumarin-isatin hybrids derivatives with antileishmanial activity. From 10 synthesized derivatives, molecular docking revealed all 10 compounds could successfully fit into the binding pocket of the target (Leishmanolysin gp63) of L. tropica. The results obtained through dynamic studies affirmed that only three compounds (Spf-6, Spf-8, and Spf-10) displayed strong binding interactions with the gp63 target. This result was experimentally validated as only these three compounds were found to be active against both promastigote and axenic amastigote forms of L. tropica. Other compounds were found to be inactive. This approach was also used by Peña-Guerrero et al., who validated the Lmj_04_BRCT domain as a novel therapeutic target in Leishmania by a structure-based drug discovery strategy, and experimentally validated in vitro a novel inhibitor (CPE2) against L. major, L. amazonensis, and L. infantum (promastigotes and intracellular amastigotes) among seven virtually selected compounds [149]. 


\section{Conclusions}

Today, (multi) drug resistance is a priority public health issue. Although medicine donation programs are multiplying to support the burden of neglected tropical diseases [150] such as leishmaniases, the pharmaceutical industry seems to increasingly restrict its research and development investment to new drug candidates [151]. Alternative options consist of repurposing drugs [152-154] or improving existing drugs, such as the gold standard amphotericin B [155]. Nevertheless, research into new drug candidates that are active against Leishmania must not be excluded, especially as methodological tools are becoming increasingly effective. Indeed, recent technological advances, such as those highlighted in this paper, should lead to new insights on parasite biology, with a view to identifying and characterizing a growing number of parasitic druggable targets in order to develop more assays against specific targets and drugs with original mechanism of action. In this way, such results may gradually lead to the development of more targeted high-throughput screenings, ideally performed on clinically relevant intramacrophagic amastigote forms, which could guide the development of a sustainable original drug candidate.

Funding: This research received no external funding.

Institutional Review Board Statement: Not applicable.

Informed Consent Statement: Not applicable.

Data Availability Statement: Not applicable.

Acknowledgments: The authors are grateful to the Aix-Marseille University, France.

Conflicts of Interest: The authors declare no conflict of interest.

\section{References}

1. World Health Organization. Leishmaniasis, 2014. Global Health Observatory. Available online: https://www.who.int/data/ gho/data/themes/topics/gho-ntd-leishmaniasis (accessed on 31 October 2021).

2. World Health Organization. A Global Brief on Vector-Borne Diseases; WHO/DCO/WHD/2014.1; World Health Organization: Geneva, Switzerland, 2014; p. 21.

3. World Health Organization. Health Topics/Leishmaniasis. Available online: https://www.who.int/health-topics/leishmaniasis\# tab=tab_1 (accessed on 3 November 2021).

4. World Health Organization. Weekly Epidemiological Record: No 25. 2020, 95, 265-280. Available online: https://apps.who.int/ iris/handle/10665/239492 (accessed on 3 November 2021).

5. World Health Organization. Control of the Leishmaniases; Technical Report Series; World Health Organization: Geneva, Switzerland, 2010; pp. 55-64.

6. Ghorbani, M.; Farhoudi, R. Leishmaniasis in humans: Drug or vaccine therapy? Drug Des. Devel. Ther. 2018, 12, 25-40. [CrossRef]

7. Chakravarty, J.; Sundar, S. Current and emerging medications for the treatment of leishmaniasis. Expert. Opin. Pharmacother. 2019, 20, 1251-1265. [CrossRef]

8. Burza, S.; Croft, S.L.; Boelaert, M. Leishmaniasis. Lancet 2018, 392, 951-970. [CrossRef]

9. Elmahallawy, E.K.; Agil, A. Treatment of leishmaniasis: A review and assessment of recent research. Curr. Pharm. Des. 2015, 21, 2259-2275. [CrossRef]

10. Croft, S.L.; Sundar, S.; Fairlamb, A.H. Drug resistance in leishmaniasis. Clin. Microbiol. Rev. 2006, 19, 111-126. [CrossRef] [PubMed]

11. Uliana, S.R.B.; Trinconi, C.T.; Coelho, A.C. Chemotherapy in leishmaniasis: Present challenges. Parasitology 2018, 145, 464-480. [CrossRef] [PubMed]

12. Sundar, S.; Singh, A.; Singh, O.P. Strategies to overcome antileishmanial drugs unresponsiveness. J. Trop. Med. 2014, $2014,646932$. [CrossRef] [PubMed]

13. Corman, H.N.; Shoue, D.A.; Norris-Mullins, B.; Melancon, B.J.; Morales, M.A.; McDowell, M.A. Development of a target-free high-throughput screening platform for the discovery of antileishmanial compounds. Int. J. Antimicrob. Agents 2019, 54, 496-501. [CrossRef]

14. De Rycker, M.; Hallyburton, I.; Thomas, J.; Campbell, L.; Wyllie, S.; Joshi, D.; Cameron, S.; Gilbert, I.H.; Wyatt, P.G.; Frearson, J.A.; et al. Comparison of a High-Throughput High-Content Intracellular Leishmania donovani assay with an axenic amastigote assay. Antimicrob. Agents Chemother. 2013, 57, 2913-2922. [CrossRef] [PubMed]

15. Siqueira-Neto, J.L.; Song, O.-R.; Oh, H.; Sohn, J.-H.; Yang, G.; Nam, J.; Jang, J.; Cechetto, J.; Lee, C.B.; Moon, S.; et al. Antileishmanial high-throughput drug screening reveals drug candidates with new scaffolds. PLoS Negl. Trop. Dis. 2011, 4, e675. [CrossRef] 
16. Mandal, S.; Maharjan, M.; Ganguly, S.; Chatterjee, M.; Singh, S.; Buckner, F.S.; Madhubala, R. High-throughput screening of amastigotes of Leishmania donovani clinical isolates against drugs using a colorimetric $\beta$-lactamase assay. Indian J. Exp. Biol. 2009, $47,475-479$.

17. Turcano, L.; Torrente, E.; Missineo, A.; Andreini, M.; Gramiccia, M.; Di Muccio, T.; Genovese, I.; Fiorillo, A.; Harper, S.; Bresciani, A.; et al. Identification and binding mode of a novel Leishmania trypanothione reductase inhibitor from high throughput screening. PloS Negl. Dis. 2018, 12, e0006969. [CrossRef]

18. Norcliffe, J.L.; Mina, J.G.; Alvarez, E.; Cantizani, J.; de Dios-Anton, F.; Colmenarejo, G.; Gonzalez-Del Valle, S.; Marco, M.; Fiandor, J.M.; Martin, J.J.; et al. Identifying inhibitors of the Leishmania inositol phosphorylceramide synthase with antiprotozoal activity using a yeast-based assay and ultra-high throughput screening platform. Sci. Rep. 2018, 8, 3938. [CrossRef]

19. Fialho Junior, L.; da Fonseca Pires, S.; Burchmore, R.; McGill, S.; Weidt, S.; Conceição Ruiz, J.; Goncalves Guimarães, F.; Chapeourouge, A.; Perales, J.; Monteiro de Andrade, H. Proteomic analysis reveals differentially abundant proteins probably involved in the virulence of amastigote and promastigote forms of Leishmania infantum. Parasitol. Res. 2021, 120, 679-692. [CrossRef] [PubMed]

20. Jara, M.; Berg, M.; Caljon, G.; de Muylder, G.; Cuypers, B.; Castillo, D.; Maes, I.; del Carmen Orozco, M.; Vanaerschot, M.; Dujardin, J.-C.; et al. Macromolecular biosynthetic parameters and metabolic profile in different life stages of Leishmania braziliensis: Amastigotes as a functionally less active stage. PLoS ONE 2017, 12, e0180532. [CrossRef] [PubMed]

21. Yao, C.; Wilson, M.E. Dynamics of sterol synthesis during development of Leishmania spp. Parasites to their virulent form. Parasit. Vectors 2016, 9, 200. [CrossRef] [PubMed]

22. Rodriguez, N.E.; Dixit, U.G.; Allen, L.-A.H.; Wilson, M.E. Stage-specific pathways of Leishmania infantum chagasi entry and phagosome maturation in macrophages. PloS ONE 2011, 6, e19000. [CrossRef] [PubMed]

23. Rosenzweig, D.; Smith, D.; Opperdoes, F.; Stern, S.; Olafson, R.W.; Zilberstein, D. Retooling Leishmania metabolism: From sand fly gut to human macrophage. FASEB J. 2008, 22, 590-602. [CrossRef] [PubMed]

24. Burge, R.J.; Damianou, A.; Wilkinson, A.J.; Rodenko, B.; Mottram, J.C. Leishmania differentiation requires ubiquitin conjugation mediated by a UBC2-UEV1 E2 complex. PLoS Pathog. 2020, 16, e1008784. [CrossRef]

25. Debrabant, A.; Joshi, M.B.; Pimenta, P.F.; Dwyer, D.M. Generation of Leishmania donovani axenic amastigotes: Their growth and biological characteristics. Int. J. Parasitol. 2004, 34, 205-217. [CrossRef]

26. Gupta, N.; Goyal, N.; Rastogi, A.K. In vitro cultivation and characterization of axenic amastigotes of Leishmania. Trends Parasitol. 2001, 17, 150-153. [CrossRef]

27. Dias-Lopes, G.; Zabala-Penafiel, A.; de Albuquerque-Melo, B.C.; Souza-Silva, F.; Menaguali do Canto, L.; Cysne-Finkelstein, L.; Alves, C.R. Axenic amastigotes of Leishmania species as a suitable model for in vitro studies. Acta Trop. 2021, $220,105956$. [CrossRef] [PubMed]

28. Bhattacharya, A.; Corbeil, A.; do Monte-Neto, R.L.; Fernandez-Prada, C. Of drugs and Trypanosomatids: New tools and knowledge to reduce bottlenecks in drug discovery. Genes 2020, 11, 722. [CrossRef] [PubMed]

29. Gupta, S.; Nishi. Visceral leishmaniasis: Experimental models for drug discovery. Indian J. Med. Res. 2011, 133, 27-39.

30. Sereno, D.; Cordeiro da Silva, A.; Mathieu-Daude, F.; Ouaissi, A. Advances and perspectives in Leishmania cell based drugscreening procedures. Parasitol. Int. 2007, 56, 3-7. [CrossRef]

31. Vermeersch, M.; da Luz, R.I.; Tote, K.; Timmermans, J.P.; Cos, P.; Maes, L. In vitro susceptibilities of Leishmania donovani promastigote and amastigote stages to antileishmanial reference drugs: Practical relevance of stage-specific differences. Antimicrob. Agents Chemother. 2009, 53, 3855-3859. [CrossRef]

32. Tegazzini, D.; Díaz, R.; Aguilar, F.; Peña, I.; Presa, J.L.; Yardley, V.; Martin, J.J.; Coteron, J.M.; Croft, S.L.; Cantizani, J. A replicative in vitro assay for drug discovery against Leishmania donovani. Antimicrob. Agents Chemother. 2016, 60, 3524-3532. [CrossRef]

33. Prada, C.F.; lvarez-Velilla, R.A.; Balana-Fouce, R.; Prieto, C.; Calvo-Alvarez, E.; Escudero-Martinez, J.M.; Requena, J.M.; Ordonez, C.; Desideri, A.; Perez-Pertejo, Y.; et al. Gimatecan and other camptothecin derivatives poison Leishmania DNA-topoisomerase IB leading to a strong leishmanicidal effect. Biochem. Pharm. 2013, 85, 1433-2440. [CrossRef]

34. Fernandez, O.; Diaz-Toro, Y.; Valderrama, L.; Ovalle, C.; Valderrama, M.; Castillo, H.; Perez, M.; Saraviaa, N.G. Novel approach to in vitro drug susceptibility assessment of clinical strains of Leishmania spp. J. Clin. Microbiol. 2012, 50, 2207-2211. [CrossRef] [PubMed]

35. Hendrickx, S.; van Bockstal, L.; Caljon, G.; Maes, L. In-depth comparison of cell-based methodological approaches to determine drug susceptibility of visceral Leishmania isolates. Plos Negl. Trop. Dis. 2019, 13, e0007885. [CrossRef]

36. Tadele, M.; Abay, S.M.; Asaga, P.; Makonnen, E.; Hailu, A. In vitro growth inhibitory activity of Medicines for Malaria Venture pathogen box compounds against Leishmania aethiopica. BMC Pharmacol. Toxicol. 2021, 22, 71. [CrossRef] [PubMed]

37. Mathur, T.; Kumar, M.; Barman, T.K.; Raj, V.S.; Upadhyay, D.J.; Verma, A.K. Novel azoles with potent antileishmanial activity. Future Microbiol. 2021, 16, 871-877. [CrossRef] [PubMed]

38. Al-Halbosiy, M.M.F.; Ali, H.Z.; Hassan, G.M.; Ghaffarifar, F. Artemisinin efficacy against old world Leishmania donovani: In Vitro and ex vivo study. Ann. Parasitol. 2020, 63, 295-302. [CrossRef]

39. Souza, J.M.; de Carvalho, E.A.A.; Candido, A.C.B.B.; de Mendonça, R.P.; Fernanda da Silva, M.; Parreira, R.L.T.; Dias, F.G.G.; Ambrosio, S.R.; Arantes, A.T.; da Silva Filho, A.A.; et al. Licochalcone a exhibits leishmanicidal activity in vitro and in experimental model of Leishmania (Leishmania) infantum. Front. Vet. Sci. 2020, 7, 527. [CrossRef] [PubMed] 
40. Monzote, L.; Herrera, I.; Satyal, P.; Setzer, W.N. In-vitro evaluation of 52 commercially-available essential oils against Leishmania amazonensis. Molecules 2019, 24, 1248. [CrossRef]

41. Antwi, C.A.; Amisigo, C.M.; Adjimani, J.P.; Gwira, T.M. In vitro activity and mode of action of phenolic compounds on Leishmania donovani. PLoS Negl. Trop. Dis. 2019, 13, e0007206. [CrossRef]

42. Fumarola, L.; Spinelli, R.; Brandonisio, O. In vitro assays for evaluation of drug activity against Leishmania spp. Res. Microbiol. 2004, 155, 224-230. [CrossRef]

43. Tempone, A.G.; Martins de Oliveira, C.; Berlinck, R.G.S. Current approaches to discover marine antileishmanial natural products. Planta Med. 2011, 77, 572-585. [CrossRef]

44. Davies-Bolorunduro, O.F.; Osuolale, O.; Saibu, S.; Adeleye, I.A.; Aminah, N.S. Bioprospecting marine actinomycetes for antileishmanial drugs: Current perspectives and future prospects. Heliyon 2021, 7, e07710. [CrossRef]

45. van den Bogaart, E.; Schoone, G.J.; England, P.; Faber, D.; Orrling, K.M.; Dujardin, J.-C.; Sundar, S.; Schallig, H.D.F.H.; Adams, E.R. Simple colorimetric trypanothione reductase-based assay for high-throughput screening of drugs against Leishmania intracellular amastigotes. Antimicrob. Agents Chemother. 2014, 58, 527-535. [CrossRef]

46. Gonzalez-Fajardo, L.; Fernández, O.L.; McMahon-Pratt, D.; Saravia, N.G. Ex vivo host and parasite response to antileishmanial drugs and immunomodulators. PLoS Negl. Trop. Dis. 2015, 9, e0003820. [CrossRef]

47. Carrio, J.; Riera, C.; Gallego, M.; Portus, M. In vitro activity of pentavalent antimony derivatives on promastigotes and intracellular amastigotes of Leishmania infantum strains from humans and dogs in Spain. Acta Trop. 2001, 79, 179-183. [CrossRef]

48. Bodley, A.L.; McGarry, M.W.; Shapiro, T.A. Drug cytotoxicity assay for African trypanosomes and Leishmania species. J. Infect. Dis. 1995, 172, 1157-1159. [CrossRef]

49. Bodley, A.L.; Shapiro, T.A. Molecular and cytotoxic effects of camptothecin, a topoisomerase I inhibitor, on trypanosomes and Leishmania. Proc. Natl Acad. Sci. USA 1995, 92, 3726-3730. [CrossRef]

50. Tada, H.; Shiho, O.; Kuroshima, K.; Koyama, M.; Tsukamoto, K. An improved colorimetric assay for interleukin 2. J. Immunol. Methods 1986, 93, 157-165. [CrossRef]

51. Khazaei, M.; Rahnama, V.; Motazedian, M.H.; Samani, S.M.; Hatam, G. In vitro effect of artemether-loaded nanostructured lipid carrier (NLC) on Leishmania infantum. J. Parasit. Dis. 2021, 45, 964-971. [CrossRef]

52. Mondêgo-Oliveira, R.; de Sá Sousa, J.C.; Moragas-Tellis, C.J.; de Souza, P.V.R.; Dos Santos Chagas, M.D.S.; Behrens, M.D.; Jesús Hardoim, D.; Taniwaki, N.N.; Chometon, T.Q.; Bertho, A.L.; et al. Vernonia brasiliana (L.) Druce induces ultrastructural changes and apoptosis-like death of Leishmania infantum promastigotes. Biomed. Pharmacother. 2021, 133, 111025. [CrossRef] [PubMed]

53. Ghosh, J.; Chakraborty, S.; Dey, S.; Mukherjee, D.; Sarkar, B.; Mallick, S.; Dutta, A.; Dutta, T.; Bhattacharjee, S.; Ghorai, N.; et al. Potential anti-leishmanial activity of a semi-purified fraction isolated from the leaves of Parthenium hysterophorus. Acta Parasitol. 2021, 66, 1480-1489. [CrossRef]

54. Rathnakar, B.; Sinha, K.K.; Prasad, S.R.; Khan, M.I.; Narsaiah, C.; Rameshwar, N.; Satyanarayana, M. Design, synthesis of biaryl piperidine derivatives and their evaluation as potential antileishmanial agents against Leishmania donovani strain Ag83. Chem. Biodivers. 2021, 18, e2100105. [CrossRef] [PubMed]

55. Guillon, J.; Cohen, A.; Das, R.N.; Boudot, C.; Gueddouda, N.M.; Moreau, S.; Ronga, L.; Savrimoutou, S.; Basmaciyan, L.; Tisnerat, C.; et al. Design, synthesis, and antiprotozoal evaluation of new 2,9-bis[(substituted-aminomethyl)phenyl]-1,10-phenanthroline derivatives. Chem. Biol. Drug Des. 2018, 91, 974-995. [CrossRef] [PubMed]

56. Fersing, C.; Boudot, C.; Pedron, J.; Hutter, S.; Primas, N.; Castera-Ducros, C.; Bourgeade-Delmas, S.; Sournia-Saquet, A.; Moreau, A.; Cohen, A.; et al. 8-Aryl-6-chloro-3-nitro-2-(phenylsulfonylmethyl)imidazo[1,2-a]pyridines as potent antitrypanosomatid molecules bioactivated by type 1 nitroreductases. Eur. J. Med. Chem. 2018, 157, 115-126. [CrossRef] [PubMed]

57. Castera-Ducros, C.; Paloque, L.; Verhaeghe, P.; Casanova, M.; Cantelli, C.; Hutter, S.; Tanguy, F.; Laget, M.; Remusat, V.; Cohen, A.; et al. Targeting the human parasite Leishmania donovani: Discovery of a new anti-infectious pharmacophore in 3-nitroimidazo[1,2-a]pyridine series. Bioorg. Med. Chem. 2013, 21, 7155-7164. [CrossRef]

58. Dutta, A.; Bandyopadhyay, S.; Mandal, C.; Chatterjee, M. Development of a modified MTT assay for screening antimonial resistant field isolates of Indian visceral leishmaniasis. Parasitol. Int. 2005, 54, 119-122. [CrossRef]

59. Williams, C.; Espinosa, O.A.; Montenegro, H.; Cubilla, L.; Capson, T.L.; Ortega-Barría, E.; Romero, L.I. Hydrosoluble formazan XTT: Its application to natural products drug discovery for Leishmania. J. Microbiol. Methods 2003, 55, 813-816. [CrossRef] [PubMed]

60. Mikus, J.; Steverding, D. A simple colorimetric method to screen drug cytotoxicity against Leishmania using the dye Alamar Blue. Parasitol. Int. 2000, 48, 265-269. [CrossRef]

61. Njanpa, C.A.N.; Wouamba, S.C.N.; Yamthe, L.R.T.; Dize, D.; Tchatat, B.M.T.; Tsouh, P.V.F.; Pouofo, M.N.; Jouda, J.B.; Ndjakou, B.L.; Sewald, N.; et al. Bio-guided isolation of anti-leishmanial natural products from Diospyros gracilescens L. (Ebenaceae). BMC Complement. Med. Ther. 2021, 21, 106. [CrossRef]

62. Zahid, M.S.H.; Johnson, M.M.; Tokarski, R.J., II; Satoskarb, A.R.; Fuchs, J.R.; Bacheldera, E.M.; Ainslie, K.M. Evaluation of synergy between host and pathogen-directed therapies against intracellular Leishmania donovani. Int. J. Parasitol. Drugs Drug Resist. 2019, 10, 125-132. [CrossRef]

63. de Sousa Araùjo, P.S.; de Oliveira, S.S.C.; d'Avila-Levy, C.M.; Dos Santos, A.L.S.; Branquinha, M.H. Susceptibility of promastigotes and intracellular amastigotes from distinct Leishmania species to the calpain inhibitor MDL28170. Parasitol. Res. 2018, 117, 20852094. [CrossRef] 
64. Carvalho, S.G.; Siqueira, L.A.; Zanini, M.S.; Dos Santos Matos, A.P.; Quaresma, C.H.; da Silva, L.M.; de Andrade, S.F.; Severi, J.A.; Villanova, J.C.O. Physicochemical and in vitro biological evaluations of furazolidone-based beta-cyclodextrin complexes in Leishmania amazonensis. Res. Vet. Sci. 2018, 119, 143-153. [CrossRef]

65. Grekov, I.; Pombinho, A.R.; Kobets, T.; Bartunek, P.; Lipoldová, M. Calcium ionophore, calcimycin, kills Leishmania promastigotes by activating parasite nitric oxide synthase. Biomed. Res. Int. 2017, 2017, 130948. [CrossRef] [PubMed]

66. Corral, M.J.; González, E.; Cuquerella, M.; Alunda, J.M. Improvement of 96-well microplate assay for estimation of cell growth and inhibition of Leishmania with Alamar Blue. J. Microbiol. Methods 2013, 94, 111-116. [CrossRef] [PubMed]

67. Kulshresta, A.; Bhandari, V.; Mukhopadhyay, R.; Ramesh, V.; Sundar, S.; Maes, L.; Dujardin, J.-C.; Roy, S.; Salotra, P. Validation of a simple resazurin-based promastigote assay for the routine monitoring of miltefosine susceptibility in clinical isolates of Leishmania donovani. Parasitol. Res. 2013, 112, 825-828. [CrossRef] [PubMed]

68. Rajabi, O.; Sazgarnia, A.; Abbasi, F.; Layegh, P. The activity of ozonated olive oil against Leishmania major promastigotes. Iran J. Basic Med. Sci. 2015, 18, 915-919.

69. Khanna, V.G.; Kannabiran, K.; Getti, G. Leishmanicidal activity of saponins isolated from the leaves of Eclipta prostrata and Gymnema sylvestre. Indian J. Pharmacol. 2009, 41, 32-35. [CrossRef]

70. Ganguly, S.; Bandyopadhyay, S.; Sarkar, A.; Chatterjee, M. Development of a semi-automated colorimetric assay for screening anti-leishmanial agents. J. Microbiol. Methods 2006, 66, 79-86. [CrossRef]

71. Want, M.Y.; Yadav, P.; Khan, R.; Chouhan, G.; Islamuddin, M.; Aloyouni, S.Y.; Chattopadhyay, A.P.; Al Omar, S.Y.; Afrin, F. Critical antileishmanial in vitro effects of highly examined gold nanoparticles. Int. J. Nanomed. 2021, 16, 7285-7295. [CrossRef]

72. Gomes-Alves, A.G.; Maia, A.F.; Cruz, T.; Castro, H.; Tomás, A.M. Development of an automated image analysis protocol for quantification of intracellular forms of Leishmania spp. PLoS ONE 2018, 13, e0201747. [CrossRef]

73. Yazdanparast, E.; Dos Anjos, A.; Garcia, D.; Loeuillet, C.; Shahbazkia, H.R.; Vergnes, B. INsPECT, an open-source and versatile software for automated quantification of (Leishmania) intracellular parasites. Plos Negl. Trop. Dis. 2014, 8, e2850. [CrossRef]

74. Moraes, C.B.; Alcântara, L.M. Quantification of parasite loads by automated microscopic image analysis. Methods Mol. Biol. 2019, 1971, 279-288. [CrossRef]

75. Costa, A.F.P.; de Brito, R.C.F.; Carvalho, L.M.; Cardoso, J.M.O.; Vieira, P.M.A.; Reis, A.B.; Aguiar-Soares, R.D.O.; Roatt, B.M. Liver infusion tryptose (LIT): The best choice for growth, viability, and infectivity of Leishmania infantum parasites. Parasitol. Res. 2020, 119, 4185-4195. [CrossRef]

76. Gadelha, A.P.R.; Brigagao, C.M.; da Silva, M.B.; Rodrigues, A.B.M.; Guimarães, A.C.R.; Paiva, F.; de Souza, W.; Henriques, C. Insights about the structure of farnesyl diphosphate synthase (FPPS) and the activity of bisphosphonates on the proliferation and ultrastructure of Leishmania and Giardia. Parasit. Vectors 2020, 13, 168. [CrossRef] [PubMed]

77. García-Bustos, M.F.; Moya Álvarez, A.; Pérez Brandan, C.; Parodi, C.; Sosa, A.M.; Buttazzoni Zuñiga, V.C.; Pastrana, O.M.; Manghera, P.; Peñalva, P.A.; Marco, J.D.; et al. Development of a fluorescent assay to search new drugs using stable tdTomatoLeishmania, and the selection of galangin as a candidate with anti-leishmanial activity. Front Cell. Infect. Microbiol. 2021, 11, 666746. [CrossRef] [PubMed]

78. Dube, A.; Gupta, R.; Singh, N. Reporter genes facilitating discovery of drugs targeting protozoan parasites. Trends Parasitol. 2009, 25, 432-439. [CrossRef] [PubMed]

79. Ertabaklar, H.; Çaliskan, S.O.; Kolli, B.; Ertug, S.; Özbilgin, A.; Malatyali, E.; Chang, K.P. Transfection of Leishmania tropica with green fluorescent protein (gfp) gene and investigation of the in vitro drug effect. Mikrobiyol. Bul. 2019, 53, 213-223. [CrossRef]

80. Pulido, S.A.; Muñoz, D.L.; Restrepo, A.M.; Mesa, C.V.; Alzate, J.F.; Vélez, I.D.; Robledo, S.M. Improvement of the green fluorescent protein reporter system in Leishmania spp. for the in vitro and in vivo screening of antileishmanial drugs. Acta Trop. 2012, 122, 36-45. [CrossRef]

81. Bolhassani, A.; Taheri, T.; Taslimi, Y.; Zamanilui, S.; Zahedifard, F.; Seyed, N.; Torkashvand, F.; Vaziri, B.; Rafati, S. Fluorescent Leishmania species: Development of stable GFP expression and its application for in vitro and in vivo studies. Exp. Parasitol. 2011, 127, 637-645. [CrossRef]

82. Bringmann, G.; Thomale, K.; Bischof, S.; Schneider, C.; Schultheis, M.; Schwarz, T.; Moll, H.; Schurigt, U. A novel Leishmania major amastigote assay in 96-well format for rapid drug screening and its use for discovery and evaluation of a new class of leishmanicidal quinolinium salts. Antimicrob. Agents Chemother. 2013, 57, 3003-3011. [CrossRef]

83. Paloque, L.; Vidal, N.; Casanova, M.; Dumètre, A.; Verhaeghe, P.; Parzy, D.; Azas, N. A new, rapid and sensitive bioluminescence assay for drug screening on Leishmania. J. Microbiol. Methods 2013, 95, 320-323. [CrossRef]

84. Michel, G.; Ferrua, B.; Lang, T.; Maddugoda, M.P.; Munro, P.; Pomares, C.; Lemichez, E.; Marty, P. Luciferase-expressing Leishmania infantum allows the monitoring of amastigote population size, in vivo, ex vivo and in vitro. PLoS Negl. Trop. Dis. 2011, 5, e1323. [CrossRef]

85. Ashutosh; Gupta, S.; Ramesh; Sundar, S.; Goyal, N. Use of Leishmania donovani field isolates expressing the luciferase reporter gene in in vitro drug screening. Antimicrob. Agents Chemother. 2005, 49, 3776-3783. [CrossRef]

86. Roy, G.; Dumas, C.; Sereno, D.; Wu, Y.; Singh, A.K.; Tremblay, M.J.; Ouellette, M.; Olivier, M.; Papadopoulou, B. Episomal and stable expression of the luciferase reporter gene for quantifying Leishmania spp. infections in macrophages and in animal models. Mol. Biochem. Parasitol. 2000, 110, 195-206. [CrossRef] 
87. Sharma, R.; Silveira-Mattos, P.S.; Ferreira, V.C.; Rangel, F.A.; Oliveira, L.B.; Celes, F.S.; Viana, S.M.; Wilson, M.E.; de Oliveira, C.I. Generation and characterization of a dual-reporter transgenic Leishmania braziliensis line expressing eGFP and Luciferase. Front. Cell. Infect. Microbiol. 2020, 9, 468. [CrossRef] [PubMed]

88. Calvo-Alvarez, E.; Cren-Travaillé, C.; Crouzols, A.; Rotureau, B. A new chimeric triple reporter fusion protein as a tool for in vitro and in vivo multimodal imaging to monitor the development of African trypanosomes and Leishmania parasites. Infect. Genet. Evol. 2018, 63, 391-403. [CrossRef] [PubMed]

89. Taheri, T.; Saberi Nik, H.; Seyed, N.; Doustdari, F.; Etemadzadeh, M.H.; Torkashvand, F.; Rafati, S. Generation of stable L. major(+EGFP-LUC) and simultaneous comparison between EGFP and luciferase sensitivity. Exp. Parasitol. 2015, 150, 44-55. [CrossRef]

90. Sadeghi, S.; Seyed, N.; Etemadzadeh, M.-H.; Abediankenari, S.; Rafati, S.; Taheri, T. In vitro infectivity assessment by drug susceptibility comparison of recombinant Leishmania major expressing enhanced green fluorescent protein or EGFP-Luciferase fused genes with wild-type parasite. Korean J. Parasitol. 2015, 53, 385-394. [CrossRef] [PubMed]

91. Calvo-Alvarez, E.; Alvarez-Velilla, R.; Fernandez-Prada, C.; Balana-Fouce, R.; Reguera, R.M. Trypanosomatids see the light: Recent advances in bioimaging research. Drug Discov. Today 2015, 20, 114-121. [CrossRef]

92. Berry, S.L.; Hameed, H.; Thomason, A.; Maciej-Hulme, M.L.; Saif Abou-Akkada, S.; Horrocks, P.; Price, H.P. Development of NanoLuc-PEST expressing Leishmania mexicana as a new drug discovery tool for axenic- and intramacrophage-based assays. PLoS Negl. Trop. Dis. 2018, 12, e0006639. [CrossRef] [PubMed]

93. Reimao, J.Q.; Oliveira, J.C.; Trinconi, C.T.; Cotrim, P.C.; Coelho, A.C.; Uliana, S.R. Generation of luciferase-expressing Leishmania infantum chagasi and assessment of miltefosine efficacy in infected hamsters through bioimaging. PLoS Negl. Trop. Dis. 2015, 9, e0003556. [CrossRef]

94. Dan-Goor, M.; Nasereddin, A.; Jaber, H.; Jaffe, C.L. Identification of a secreted casein kinase 1 in Leishmania donovani: Effect of protein over expression on parasite growth and virulence. PLoS ONE 2013, 8, e79287. [CrossRef]

95. Price, H.P.; Paape, D.; Hodgkinson, M.R.; Farrant, K.; Doehl, J.; Stark, M.; Smith, D.F. The Leishmania major BBSome subunit BBS1 is essential for parasite virulence in the mammalian host. Mol. Microbiol. 2013, 90, 597-611. [CrossRef]

96. Agostino, V.S.; Trinconi, C.M.; Galuppo, M.K.; Price, H.; Uliana, S.R.B. Evaluation of NanoLuc, RedLuc and Luc2 as bioluminescent reporters in a cutaneous leishmaniasis model. Acta Trop. 2020, 206, 105444. [CrossRef]

97. ClinicalTrials.gov. National Library of Medicine (NLM), National Institutes of Health (NIH). Available online: https:// clinicaltrials.gov/ct2/home (accessed on 31 October 2021).

98. Ivens, A.C.; Peacock, C.S.; Worthey, E.A.; Murphy, L.; Aggarwal, G.; Berriman, M.; Sisk, E.; Rajandream, M.A.; Adlem, E.; Aert, R.; et al. The genome of the kinetoplastid parasite, Leishmania major. Science 2005, 309, 436-442. [CrossRef]

99. Myler, P.J.; Fasel, N. Leishmania: After the Genome; Caister Academic Press: Norfolk, UK, 2008.

100. Cruz, A.K.; Freitas-Castro, F. Genome and transcriptome analyses of Leishmania spp.: Opening Pandora's box. Curr. Opin. Microbiol. 2019, 52, 64-69. [CrossRef]

101. Salloum, T.; Tokajian, S.; Hirt, R.P. Advances in understanding Leishmania pathobiology: What does RNA-Seq tell us? Front. Cell Dev. Biol. 2021, 9, 702240. [CrossRef] [PubMed]

102. Dubessay, P.; Ravel, C.; Bastien, P.; Crobu, L.; Dedet, J.P.; Pages, M.; Blaineau, C. The switch region on Leishmania major chromosome 1 is not required for mitotic stability or gene expression, but appears to be essential. Nucleic Acids Res. 2002, 30, 3692-3697. [CrossRef]

103. Mantravadi, P.K.; Parthasarathy, A.; Kalesh, K. Antileishmanial drug development: A review of modern molecular chemical tools and research strategies. Curr. Med. Chem. 2021, 28, 6337-6357. [CrossRef] [PubMed]

104. Altamura, F.; Rajesh, R.; Catta-Pretta, C.M.C.; Moretti, N.S.; Cestari, I. The current drug discovery landscape for trypanosomiasis and leishmaniasis: Challenges and strategies to identify drug targets. Drug Dev. Res. 2020, 1-28. [CrossRef] [PubMed]

105. Jones, N.G.; Catta-Pretta, C.M.C.; Lima, A.P.C.A.; Mottram, J.C. Genetically validated drug targets in Leishmania: Current knowledge and future prospects. ACS Infect. Dis. 2018, 4, 467-477. [CrossRef]

106. Agoni, C.; Olotu, F.A.; Ramharack, P.; Soliman, M.E. Druggability and drug-likeness concepts in drug design: Are biomodelling and predictive tools having their say? J. Mol. Model. 2020, 26, 120. [CrossRef]

107. Wyatt, P.G.; Gilbert, I.H.; Read, K.D.; Fairlamb, A.H. Target validation: Linking target and chemical properties to desired product profile. Curr. Top. Med. Chem. 2011, 11, 1275-1283. [CrossRef] [PubMed]

108. Atayde, V.D.; Shi, H.; Franklin, J.B.; Carriero, N.; Notton, T.; Lye, L.-F.; Owens, K.; Beverley, S.M.; Tschudi, C.; Ullu, E. The structure and repertoire of small interfering RNAs in Leishmania (Viannia) braziliensis reveal diversification in the trypanosomatid RNAi pathway. Mol. Microbiol. 2013, 87, 580-593. [CrossRef]

109. Robinson, K.A.; Beverley, S.M. Improvements in transfection efficiency and tests of RNA interference (RNAi) approaches in the protozoan parasite Leishmania. Mol. Biochem. Parasitol. 2003, 128, 217-228. [CrossRef]

110. Beverley, S.M. Protozomics: Trypanosomatid parasite genetics comes of age. Nat. Rev. Genet. 2003, 4, 11-19. [CrossRef] [PubMed]

111. Da Rocha, W.D.; Otsu, K.; Teixeira, S.M.R.; Donelson, J.E. Tests of cytoplasmic RNA interference (RNAi) and construction of a tetracycline-inducible T7 promoter system in Trypanosoma cruzi. Mol. Biochem. Parasitol. 2004, 133, 175-186. [CrossRef]

112. Ullu, E.; Tschudi, C.; Chakraborty, T. RNA interference in protozoan parasites. Cell. Microbiol. 2004, 6, 509-519. [CrossRef] [PubMed] 
113. De Paiva, R.M.C.; Grazielle-Silva, V.; Cardoso, M.S.; Nakagaki, B.N.; Mendonça-Neto, R.P.; Canavaci, A.M.; Souza Melo, N.; Martinelli, P.M.; Fernandes, A.P.; da Rocha, W.D.; et al. Amastin knockdown in Leishmania braziliensis affects parasite-macrophage interaction and results in impaired viability of intracellular amastigotes. PLoS Pathog. 2015, 11, e1005296. [CrossRef] [PubMed]

114. Duncan, S.M.; Myburgh, E.; Philipon, C.; Brown, E.; Meissner, M.; Brewer, J.; Mottram, J.C. Conditional gene deletion with DiCre demonstrates an essential role of CRK3 in Leishmania mexicana cell cycle regulation. Mol. Microbiol. 2016, 100, 931-944. [CrossRef]

115. Grewal, J.S.; Catta-Pretta, C.M.C.; Brown, E.; Anand, J.; Mottram, J.C. Evaluation of clan CD C11 peptidase PNT1 and other Leishmania mexicana cysteine peptidases as potential drug targets. Biochimie 2019, 166, 150-160. [CrossRef]

116. Bhattacharyya, S.; Dey, R.; Majumder, N.; Bhattacharjeen, S.; Majumdar, S. A novel approach to regulate experimental visceral leishmaniasis in murine macrophages using CCR5 siRNA. Scand. J. Immunol. 2008, 67, 345-353. [CrossRef]

117. Chakraborty, A.; Kurati, S.P.; Mahata, S.K.; Sundar, S.; Roy, S.; Sen, M. Wnt5a Signaling promotes host defense against Leishmania donovani infection. J. Immunol. 2017, 199, 992-1002. [CrossRef] [PubMed]

118. Minet, C.; Thévenon, S.; Chantal, I.; Solano, P.; Berthier, D. Mini-review on CRISPR-Cas9 and its potential applications to help controlling neglected diseases caused by Trypanosomatidae. Infect. Genet. Evol. 2018, 63, 326-331. [CrossRef] [PubMed]

119. Jinek, M.; Chylinski, K.; Fonfara, I.; Hauer, M.; Doudna, J.A.; Charpentier, E. A programmable dual-RNA-guided DNA endonuclease in adaptive bacterial immunity. Science 2012, 337, 816-821. [CrossRef]

120. Jiang, F.; Doudna, J.A. CRISPR-Cas9 structures and mechanisms. Annu. Rev. Biophys. 2017, 46, 505-529. [CrossRef]

121. Sollelis, L.; Ghorbal, M.; MacPherson, C.R.; Martins, R.M.; Kuk, N.; Crobu, L.; Bastien, P.; Scherf, A.; Lopez-Rubio, J.-J.; Sterkers, Y. First efficient CRISPR-Cas9-mediated genome editing in Leishmania parasites. Cell. Microbiol. 2015, 17, 1405-1412. [CrossRef]

122. Zhang, W.-W.; Matlashewski, G. CRISPR-Cas9-mediated genome editing in Leishmania donovani. MBio 2015, 6, e00861-15. [CrossRef]

123. Duncan, S.M.; Jones, N.G.; Mottram, J.C. Recent advances in Leishmania reverse genetics: Manipulating a manipulative parasite. Mol. Biochem. Parasitol. 2017, 216, 30-38. [CrossRef]

124. Laffitte, M.-C.N.; Leprohon, P.; Hainse, M.; Légaré, D.; Masson, J.-Y.; Ouellette, M. Chromosomal translocations in the parasite Leishmania by a MRE11/RAD50-independent microhomology-mediated end joining mechanism. PLoS Genet. 2016, 12, e1006117. [CrossRef] [PubMed]

125. Zhang, W.-W.; Lypaczewski, P.; Matlashewski, G. Optimized CRISPR-Cas9 genome editing for Leishmania and its use to target a multigene family, induce chromosomal translocation, and study DNA break repair mechanisms. MSphere 2017, 2, e00340-16. [CrossRef]

126. Damasceno, J.D.; Reis-Cunha, J.; Crouch, K.; Beraldi, D.; Lapsley, C.; Tosi, L.R.O.; Bartholomeu, D.; McCulloch, R. Conditional knockout of RAD51-related genes in Leishmania major reveals a critical role for homologous recombination during genome replication. PLoS Genet. 2020, 16, e1008828. [CrossRef]

127. Beneke, T.; Madden, R.; Makin, L.; Valli, J.; Sunter, J.; Gluenz, E. A CRISPR Cas9 high-throughput genome editing toolkit for kinetoplastids. R. Soc. Open Sci. 2017, 4, 170095. [CrossRef]

128. Martel, D.; Beneke, T.; Gluenz, E.; Späth, G.F.; Rachidi, N. Characterisation of casein kinase 1.1 in Leishmania donovani using the CRISPR Cas 9 toolkit. BioMed Res. Int. 2017, 4635604. [CrossRef]

129. Shrivastava, R.; Tupperwar, N.; Drory-Retwitzer, M.; Shapira, M. Deletion of a single LeishIF4E-3 allele by the CRISPR Cas9 system alters cell morphology and infectivity of Leishmania. MSphere 2019, 4, e00450-19. [CrossRef]

130. Baker, N.; Catta-Preta, C.M.C.; Neish, R.; Sadlova, J.; Powell, B.; Alves-Ferreira, E.V.C.; Geoghegan, V.; Carnielli, J.B.T.; Newling, K.; Hughes, C.; et al. Systematic functional analysis of Leishmania protein kinases identifies regulators of differentiation or survival. Nat. Commun. 2021, 12, 1244. [CrossRef]

131. Cowell, A.N.; Winzeler, E.A. Advances in omics-based methods to identify novel targets for malaria and other parasitic protozoan infections. Genome Med. 2019, 11, 63. [CrossRef]

132. Cantacessi, C.; Dantas-Torres, F.; Nolan, M.J.; Otranto, D. The past, present, and future of Leishmania genomics and transcriptomics. Trends Parasitol. 2015, 31, 100-108. [CrossRef]

133. Luth, M.R.; Gupta, P.; Ottilie, S.; Winzeler, E.A. Using in vitro evolution and whole genome analysis to discover next generation targets for antimalarial drug discovery. ACS Infect. Dis. 2018, 4, 301-314. [CrossRef]

134. Khare, S.; Nagle, A.S.; Biggart, A.; Lai, Y.H.; Liang, F.; Davis, L.C.; Barnes, S.W.; Mathison, C.J.N.; Myburgh, E.; Gao, M.-Y.; et al. Proteasome inhibition for treatment of leishmaniasis, Chagas disease and sleeping sickness. Nature 2016, 537, 229-233. [CrossRef]

135. Wyllie, S.; Thomas, M.; Patterson, S.; Crouch, S.; De Rycker, M.; Lowe, R.; Gresham, S.; Urbaniak, M.D.; Otto, T.D.; Stojanovski, L.; et al. Cyclin-dependent kinase 12 is a drug target for visceral leishmaniasis. Nature 2018, 560, 192-197. [CrossRef] [PubMed]

136. Patti, G.J.; Yanes, O.; Siuzdak, G. Metabolomics: The apogee of the omics trilogy. Nat. Rev. Mol. Cell. Biol. 2012, 13, $263-269$. [CrossRef] [PubMed]

137. Rojo, D.; Canuto, G.A.; Castilho-Martins, E.A.; Tavares, M.F.; Barbas, C.; Lopez-Gonzalvez, A.; Rivas, L. A multiplatform metabolomic approach to the basis of antimonial action and resistance in Leishmania infantum. PLoS ONE 2015, 10, e0130675. [CrossRef]

138. Vendruscolo, M.H.; das Neves, G.M.; Kagami, L.P.; Rodrigues Junior, L.C.; Nunes Diehl, M.L.; Gnoatto, S.C.B.; de Loreto Bordignon, S.A.; Romão, P.R.T.; Eifler-Lima, V.L.; von Poser, G.L. In vitro and in silico activity of iridoids against Leishmania amazonensis. Curr. Drug Discov. Technol. 2019, 16, 173-183. [CrossRef] 
139. Kumar, V.; Sri, N.S.; Tripathi, N.; Sharma, V.K.; Bharatam, P.V.; Garg, P.; Singh, S. Structural exploration of glutamine synthetase from Leishmania donovani: Insights from in silico and in vitro analysis. Int. J. Biol. Macromol. 2020, 146, 860-874. [CrossRef]

140. Saki, J.; Shadnoush, F.; Arjmand, R.; Rahim, F. In-silico identification of the best compound against Leishmania infantum: High throughput screening of all FDA approved drugs. Turkiye Parazitol. Derg. 2019, 43, 158-164. [CrossRef] [PubMed]

141. Wadanambi, P.M.; Mannapperuma, U. Computational study to discover potent phytochemical inhibitors against drug target, squalene synthase from Leishmania donovani. Heliyon 2021, 7, e07178. [CrossRef] [PubMed]

142. Sharma, V.K.; Bharatam, P.V. Identification of selective inhibitors of LdDHFR enzyme using pharmacoinformatic methods. J. Comput. Biol. 2021, 28, 43-59. [CrossRef] [PubMed]

143. Souza, B.C.; Lacerda, P.S.; Pita, S.S.D.R.; Kato, R.B.; Leite, F.H.A. Identification of potential Leishmania chagasi superoxide dismutase allosteric modulators by structure-based computational approaches: Homology modelling, molecular dynamics and pharmacophore-based virtual screening. J. Biomol. Struct. Dyn. 2021, 39, 7000-7016. [CrossRef] [PubMed]

144. Bisht, N.; Sah, A.N.; Bisht, S.; Joshi, H. Emerging need of today: Significant utilization of various databases and softwares in drug design and development. Mini Rev. Med. Chem. 2021, 21, 1025-1032. [CrossRef]

145. Tran-Nguyen, V.K.; Jacquemard, C.; Rognan, D. LIT-PCBA: An unbiased data set for machine learning and virtual screening. J. Chem. Inf. Model. 2020, 60, 4263-4273. [CrossRef]

146. Maia, M.D.S.; Silva, J.P.R.E.; Nunes, T.A.L.; Sousa, J.M.S.; Rodrigues, G.C.S.; Monteiro, A.F.M.; Tavares, J.F.; Rodrigues, K.A.D.F.; Mendonça-Junior, F.J.B.; Scotti, L.; et al. Virtual screening and the in vitro assessment of the antileishmanial activity of Lignans. Molecules 2020, 25, 2281. [CrossRef]

147. Sasidharan, S.; Saudagar, P. Flavones reversibly inhibit Leishmania donovani tyrosine aminotransferase by binding to the catalytic pocket: An integrated in silico-in vitro approach. Int. J. Biol. Macromol. 2020, 164, 2987-3004. [CrossRef]

148. Khatoon, S.; Aroosh, A.; Islam, A.; Kalsoom, S.; Ahmad, F.; Hameed, S.; Abbasi, S.W.; Yasinzai, M.; Naseer, M.M. Novel coumarin-isatin hybrids as potent antileishmanial agents: Synthesis, in silico and in vitro evaluations. Bioorg. Chem. 2021, 110, 104816. [CrossRef] [PubMed]

149. Peña-Guerrero, J.; Fernández-Rubio, C.; Burguete-Mikeo, A.; El-Dirany, R.; García-Sosa, A.T.; Nguewa, P. Discovery and validation of Lmj_04_BRCT domain, a novel therapeutic target: Identification of candidate drugs for leishmaniasis. Int. J. Mol. Sci. 2021, 22, 10493. [CrossRef]

150. Bradley, M.; Taylor, R.; Jacobson, J.; Guex, M.; Hopkins, A.; Jensen, J.; Leonard, L.; Waltz, J.; Kuykens, L.; Sow, P.S.; et al. Medicine donation programmes supporting the global drive to end the burden of neglected tropical diseases. Trans. R. Soc. Trop. Med. Hyg. 2021, 115, 136-144. [CrossRef] [PubMed]

151. Ardal, C.; Balasegaram, M.; Laxminarayan, R.; McAdams, D.; Outterson, K.; Rex, J.H.; Sumpradit, N. Antibiotic developmenteconomic, regulatory and societal challenges. Nat. Rev. Microbiol. 2020, 18, 267-274. [CrossRef]

152. Tabrez, S.; Rahman, F.; Ali, R.; Muhammad, F.; Alshehri, B.M.; Alaidarous, M.A.; Banawas, S.; Dukhyil, A.A.B.; Rub, A. Repurposing of FDA-approved drugs as inhibitors of sterol C-24 methyltransferase of Leishmania donovani to fight against leishmaniasis. Drug Dev. Res. 2021, 82, 1154-1161. [CrossRef]

153. Andrade-Neto, V.V.; da Silva Pacheco, J.; Inácio, J.D.; Almeida-Amaral, E.E.; Torres-Santos, E.C.; Cunha-Junior, E.F. Efficacy of spironolactone treatment in murine models of cutaneous and visceral leishmaniasis. Front. Pharmacol. 2021, 12, 636265. [CrossRef]

154. Costa, R.R.; Oliveira-da-Silva, J.A.; Reis, T.A.R.; Tavares, G.S.V.; Mendonça, D.V.C.; Freitas, C.S.; Lage, D.P.; Martins, V.T.; Antinarelli, L.M.R.; Machado, A.S.; et al. Acarbose presents in vitro and in vivo antileishmanial activity against Leishmania infantum and is a promising therapeutic candidate against visceral leishmaniasis. Med. Microbiol. Immunol. 2021, 210, 133-147. [CrossRef]

155. Lanza, J.S.; Pomel, S.; Loiseau, P.M.; Frézard, F. Recent advances in amphotericin B delivery strategies for the treatment of leishmaniases. Expert Opin. Drug Deliv. 2019, 16, 1063-1079. [CrossRef] [PubMed] 